\title{
Requirements Analysis and Arabic M-Learning Activities Module Design in the Institute of Teacher Education (ITE) in Malaysia
}

\author{
Amani Dahaman ${ }^{1}$, Zawawi Ismail ${ }^{2}$, Norasikin Fabil ${ }^{3}$ \\ ${ }^{1}$ Institut Pendidikan Guru Kampus Perlis, Malaysia \\ ${ }^{2}$ University of Malaya, Malaysia \\ ${ }^{3}$ Islamic Science University of Malaysia \\ Email: amanidahaman@yahoo.com,zawawiismail@um.edu.my,norasikinfabil@yahoo.com
}

Received 2012

\begin{abstract}
This study is aimed to identify the student needs for Arabic M-learning modules in Institute of Teacher Education (ITE) in Malaysia. The sample comprises 150 respondents, 120 respondents were among the Bachelor of Teaching Program students (Majoring in Arabic and Islamic Studies) and 30 respondents were the Arabic lecturers from the Institute of Teacher Education in Malaysia. The instrument used was a refurbished questionnaire from the M-Learning Curriculum Requirements (Ahmad Sobri, 2009). The findings presented the selection of mobile computing technology as the main equipment in the application of Arabic m-learning in the ITE, website platform as its operation and email communications are more dominant compared to SMS and MMS. Similarly, the pattern of appropriate learning activities is included in the M-learning which focused on activities that in line with the use of mobile computer technology.
\end{abstract}

Keywords: M-learning Activities; Module Design; Arabic and Islamic Studies

\section{Introduction}

Education Development Master Plan (EDMP) 2006-2010, Ministry of Education aims continuous efforts to enhance the curriculum development of Arabic Language at the Malay-sian Institute of Teacher Education (ITE) which leads to Graduate programs for the Arabic teachers holding a Bache-lor of Teaching (Ministry of Education, 2006) . The plan generally has an effect on the declaration of the Government of Malaysia in upgrading the Teaching College to ITE.

The declaration provides a major change to the teaching institution in Malaysia with the commencement of Graduate Teaching Program conducted in the institute for instance Primary Teaching Graduate Program (PGSR) and recogni-tion of Bachelor degree to primary school teachers through a Bachelor of Teaching Program (PISMP) and B. Ed TESL (Asariah Mior Shaharuddin et.al, 2011).

Furthermore, the condition encouraged the impact of re-quirements for the Arabic teachers who are positioned in the national schools. To meet the needs of these teachers the Institute of Teacher Education (ITE) has been given the role to offer Bachelor of Teaching Program (PISMP) to SPM students through the formulation of the Arabic curriculum specifically for the program. The curriculum is specifically designed to give emphasis to the language skills for instance listening, speaking, reading and writing, teaching and educa-tion specifically to guide and prepare teachers who are capa-ble of Arabic language and linguistics and has a Bachelor of Teaching Arabic (Abdul Aziz Mahayuddin, 2008).

The establishment of the program implementation is proved with the involvement from the Division of Teacher Educa-tion (BPG). Division of Teacher Education (2010) through ITE Resolution Seminar in Islamic \& Arabic Education, decided a proposal to establish a strategy or a module that can integrate learning materials, reference resources, interac-tion of students and lecturers in all courses involving Islamic education and Arabic. The strategy or the module will enable the partnership and interaction between teachers hence forming a learning process of sharing knowledge, experi-ences and skills of each student.

The integration process of learning the Arabic language has been successfully implemented at the institutions of higher learning in Syria through the Arabic Self Learning Module involving native-speaking students of Arabic lan-guage from various courses and educational background (Nimat Hafez, 2005). Hence, the success of this research has achieved major impetus in the construction of the Arabic M-learning module design for non-Arabic speakers at the ITE in Malaysia.

\section{Objectives of the Study}

The objective of this study is to identify the requirements and the design activities for the Arabic M-Learning module in the Institute of Teacher Education (ITE).

There are three research questions that will be answered in the study related to the two main elements of the hardware and requirements operating platform requirements and communication features and the Arabic m-learning activities design in ITE.

a) What are the hardware requirements that are suitable for the Arabic m-learning module in ITE?

b) What are the suitable operating platforms for the Arabic m-learning module in the ITE?

c) What are the appropriate communications criteria for the Arabic m-learning module in the ITE?

d) What design patterns of learning activities that are suitable for the Arabic m-learning module in the ITE?

\section{Research Background}

Among the earliest studies in the field of M-Learning in Ma- 
laysia were studies on the implementation evaluation of $\mathrm{M}$ learning program to some standard five students of a primary school in Kuala Lumpur (Saedah Siraj and Norlida Alias, 2005). The purpose of this study was to investigate whether the implementation of M-learning program has achieved the aspirations set out on it and also assesses the strengths and weaknesses of the program.

Syed Ardi Bin Syed Yahya Syed Kamal \& Zaidatun Tasir (2008) discussed the future of learning refers to the shift in the era of eLearning technology to mLearning. Study of Nabeel Farouq (2008) involved the development of M-Learning model in quality of service in the university environment. He does not focus on the learning system but the services system in the university which benefit the students

Goh Chin Shuang et.al (2009) reviewed the student feedback on the application of M-Learning in foreign language learning. Hayati Hashim et.al (2009) made an overview of the students' perceptions on M-Learning in educational institutions. Whilst, Mariam Mohamad \& John Woollard (2009) focused on learning strategies in English learning strategies in secondary schools in Malaysia.

Ahmad Sobri Shuib (2009) conducted the study of M-Learning curriculum design for the secondary schools. This study was the design and development of three phases; requirements analysis phase, the design phase and the evaluation phase. The results showed that the implementation of a prototype module for the Form 1 History subject in secondary schools in Jitra, Kedah has achieved its resolution based on the 'Stake Countenance'.

\section{Research Methodology}

In this study, researcher conducted a need analysis through a survey using five Likert scale questionnaire. A total of 150 students from Bachelor in Teaching Program (PISMP) who take Arabic as a subject in several selected Institute of Teacher Education (ITE) in Malaysia and 30 Arabic lecturers from some selected Institute of Teacher Education.

Before the questionnaire was distributed, the researcher conducted a pilot study for validity and reliability. Require- ments analysis is conducted to determine the needs for the Arabic ( $\mathrm{M} \sim \mathrm{Mu}$ 'allim) M-learning design modules at the Institute of Teacher Education.

The researcher has outlined the procedure:

1) Identifying the target group or focused groups

2) Conduct a need analysis on students and lecturers

3) The pilot study was conducted before the questionnaire was distributed in this phase.

The pilot study for the questionnaire instruments involves 30 samples. Alpha reliability of the survey instrument with 16 items was 0.71 .

\section{Research Findings and Discussion}

The findings was presented based on (a) the need to involve software and hardware used and (b) the design of learning activities used in the Arabic m-learning in the ITE.

Table 1 shows the frequency and hardware requirements mean of mobile technology that can be used in the Arabic mlearning at ITE. The sequence based on the highest mean value of equipment needs, led by laptops (mean $=4.54)$, netbook (mean $=4.41)$ and tablet computers (mean $=4.01)$. While four other hardwares to get the mean of less than 4.0 are smart telephone (mean = 3.86), 3G handphone $($ mean $=3.76)$, PDA (min $=3: 37$ ) and mobile phone (3.27).

These findings clearly show the pattern selection of equipment which has been chosen in learning Arabic which is based on the mobile computer technology equipment. The users of Arabic m-learning are preferable to use the tools of technology based mobile computer compared to the usage of mobile phone technology. Sharma \& Kitchens (2004) compared the traditional learning concept with the concept of M-learning that has changed the existing concept of learning in terms of the learning environment and school components curriculum, the teachers and students.

Users are less likely to use mobile phone technology to support learning Arabic. The usage of mobile phone is restricted to medium of communication rather than making it as a medium of learning.

Table 1.

Hardware requirements of mobile technology in learning.

\begin{tabular}{|c|c|c|c|c|c|c|}
\hline & Strongly Disagree & Disagree & Uncertain & Agree & Strongly agree & \\
\hline & $\begin{array}{l}\text { No } \\
\text { (\%) }\end{array}$ & $\begin{array}{l}\text { No } \\
\text { (\%) }\end{array}$ & $\begin{array}{l}\text { No } \\
\text { (\%) }\end{array}$ & $\begin{array}{l}\text { No } \\
\text { (\%) }\end{array}$ & $\begin{array}{l}\text { No } \\
\text { (\%) }\end{array}$ & Mean \\
\hline Laptop & $\begin{array}{c}0 \\
(0)\end{array}$ & $\begin{array}{c}0 \\
(0)\end{array}$ & $\begin{array}{c}3 \\
(1.7)\end{array}$ & $\begin{array}{c}76 \\
(42.2)\end{array}$ & $\begin{array}{c}101 \\
(56.1)\end{array}$ & 4.54 \\
\hline Netbook & $\begin{array}{c}0 \\
(0)\end{array}$ & $\begin{array}{c}0 \\
(0)\end{array}$ & $\begin{array}{c}17 \\
(9.4)\end{array}$ & $\begin{array}{c}72 \\
(40)\end{array}$ & $\begin{array}{c}91 \\
(50.6)\end{array}$ & 4.41 \\
\hline Tablet Computer & $\begin{array}{c}0 \\
(0)\end{array}$ & $\begin{array}{c}1 \\
(0.6)\end{array}$ & $\begin{array}{c}47 \\
(26.1)\end{array}$ & $\begin{array}{c}81 \\
(45)\end{array}$ & $\begin{array}{c}51 \\
(28.3)\end{array}$ & 4.01 \\
\hline Smartphone & $\begin{array}{c}0 \\
(0)\end{array}$ & $\begin{array}{c}11 \\
(6.1)\end{array}$ & $\begin{array}{c}51 \\
(28.3)\end{array}$ & $\begin{array}{c}70 \\
(38.9)\end{array}$ & $\begin{array}{c}48 \\
(26.7)\end{array}$ & 3.86 \\
\hline 3G Handphone & $\begin{array}{c}1 \\
0.6)\end{array}$ & $\begin{array}{c}8 \\
(4.4)\end{array}$ & $\begin{array}{c}53 \\
(29.4)\end{array}$ & $\begin{array}{c}89 \\
(49.4)\end{array}$ & $\begin{array}{c}29 \\
(16.1)\end{array}$ & 3.76 \\
\hline PDA & $\begin{array}{c}4 \\
(2.2)\end{array}$ & $\begin{array}{c}27 \\
(15)\end{array}$ & $\begin{array}{c}73 \\
(40.6)\end{array}$ & $\begin{array}{c}50 \\
(27.8)\end{array}$ & $\begin{array}{c}26 \\
(14.4)\end{array}$ & 3.37 \\
\hline Mobile Phone & $\begin{array}{c}13 \\
(7.2)\end{array}$ & $\begin{array}{c}36 \\
(20)\end{array}$ & $\begin{array}{c}44 \\
(24.4)\end{array}$ & $\begin{array}{c}64 \\
(35.6)\end{array}$ & $\begin{array}{c}23 \\
(12.8)\end{array}$ & 3.27 \\
\hline
\end{tabular}


Table 2 shows the frequency and mean of operating platforms and communication features in Arabic m-learning in the ITE. The findings showed that respondents were more likely to choose a website as a platform for Arabic m-learning (mean = 4.47) compared to blog which is much lower (mean 4.33).

The findings of the study showed that the respondents are more comfortable using email as a communication feature in m-learning with a high mean of 4.28 . While the other three elements scored the mean less than 4.0 which were the use of chat as communication features in m-learning (mean $=3.71$ ), SMS (mean 3.70) and MMS (mean = 2.87).

The findings were equivalent with the previous findings (see Table 1) related to the use of hardware-oriented mobile computing technology. The choice of website and email platform is based on portable computer technology oriented.

Table 3 shows the frequency and the mean of appropriate learning activities in Arabic M-Learning at ITE. The findings show that the learning activities are concerned with the oneway interaction or delayed bilateral interaction which chosen by the respondents. This can be seen by the downloading of materials $($ mean $=4: 59)$, notes reading $($ mean $=4: 56)$, finding information (min 4:43), and quizzes (mean 4.39).

Activities that involve delayed bilateral interaction can also be seen in the use of forum activity (mean $=4: 56$ ) and email (mean 4.25). These activities have interactive features but not in direct.

Activities that are more dominant in the use of mobile computer technology equipment are still at the highest position among the respondents. They believed that mobile -oriented learning activity like SMS (mean = 3.86) and MMS (mean 3.49) as well as chat (mean $=3.87$ ). Independent ability in learning needs to be applied with the help of ICT and learning materials that complement the latest technology (Ghazali Eric et al., 2011).

Table 2.

Operating platform requirements and communication features in m-learning.

\begin{tabular}{|c|c|c|c|c|c|c|}
\hline & Strongly Disagree & Disagree & Uncertain & Agree & Strongly Agree & \multirow[b]{2}{*}{ Mean } \\
\hline & $\begin{array}{l}\text { No } \\
(\%)\end{array}$ & $\begin{array}{l}\text { No } \\
(\%)\end{array}$ & $\begin{array}{l}\text { No } \\
(\%)\end{array}$ & $\begin{array}{l}\text { No } \\
(\%)\end{array}$ & $\begin{array}{l}\text { No } \\
\text { (\%) }\end{array}$ & \\
\hline Website & $\begin{array}{c}0 \\
(0)\end{array}$ & $\begin{array}{c}1 \\
(0.6)\end{array}$ & $\begin{array}{c}5 \\
(2.8)\end{array}$ & $\begin{array}{c}83 \\
(46.1)\end{array}$ & $\begin{array}{c}91 \\
(50.6)\end{array}$ & 4.47 \\
\hline Blog & $\begin{array}{c}0 \\
(0)\end{array}$ & $\begin{array}{c}0 \\
(0)\end{array}$ & $\begin{array}{c}12 \\
(6.7)\end{array}$ & $\begin{array}{c}97 \\
(53.9)\end{array}$ & $\begin{array}{c}71 \\
(39.4)\end{array}$ & 4.33 \\
\hline Email & $\begin{array}{c}0 \\
(0)\end{array}$ & $\begin{array}{c}1 \\
(0.6)\end{array}$ & $\begin{array}{c}15 \\
(8.3)\end{array}$ & $\begin{array}{c}96 \\
(53.3)\end{array}$ & $\begin{array}{c}68 \\
(37.8)\end{array}$ & 4.28 \\
\hline Chat & $\begin{array}{c}5 \\
(2.8)\end{array}$ & $\begin{array}{c}13 \\
(7.2)\end{array}$ & $\begin{array}{c}43 \\
(23.9)\end{array}$ & $\begin{array}{c}88 \\
(48.9)\end{array}$ & $\begin{array}{c}31 \\
(17.2)\end{array}$ & 3.71 \\
\hline SMS & $\begin{array}{c}0 \\
(0)\end{array}$ & $\begin{array}{c}23 \\
(12.8)\end{array}$ & $\begin{array}{c}41 \\
(22.8)\end{array}$ & $\begin{array}{c}83 \\
(46.1)\end{array}$ & $\begin{array}{c}33 \\
(18.3)\end{array}$ & 3.70 \\
\hline MMS & $\begin{array}{c}20 \\
(11.1)\end{array}$ & $\begin{array}{c}36 \\
(20)\end{array}$ & $\begin{array}{c}75 \\
(41.7)\end{array}$ & $\begin{array}{c}45 \\
(25)\end{array}$ & $\begin{array}{c}4 \\
(2.2)\end{array}$ & 2.87 \\
\hline
\end{tabular}

Table 3.

Proposed learning activities in Arabic M-Learning.

\begin{tabular}{|c|c|c|c|c|c|c|}
\hline & Strongly Disagree & Disagree & Uncertain & Agree & Strongly Agree & \multirow{2}{*}{ Mean } \\
\hline & $\begin{array}{l}\text { No } \\
(\%)\end{array}$ & $\begin{array}{l}\text { No } \\
(\%)\end{array}$ & $\begin{array}{l}\text { No } \\
(\%)\end{array}$ & $\begin{array}{l}\text { No } \\
(\%)\end{array}$ & $\begin{array}{l}\text { No } \\
(\%)\end{array}$ & \\
\hline Downloading P\&P materials & $\begin{array}{c}0 \\
(0)\end{array}$ & $\begin{array}{c}0 \\
(0)\end{array}$ & $\begin{array}{c}7 \\
(3.9)\end{array}$ & $\begin{array}{c}61 \\
(33.9)\end{array}$ & $\begin{array}{c}112 \\
(62.2)\end{array}$ & 4.59 \\
\hline Forum & $\begin{array}{c}0 \\
(0)\end{array}$ & $\begin{array}{c}0 \\
(0)\end{array}$ & $\begin{array}{c}6 \\
(3.3)\end{array}$ & $\begin{array}{c}67 \\
(37.2)\end{array}$ & $\begin{array}{c}107 \\
(59.4)\end{array}$ & 4.56 \\
\hline Notes reading & $\begin{array}{c}0 \\
(0)\end{array}$ & $\begin{array}{c}0 \\
(0)\end{array}$ & $\begin{array}{c}4 \\
(2.2)\end{array}$ & $\begin{array}{c}71 \\
(39.4)\end{array}$ & $\begin{array}{c}105 \\
(58.3)\end{array}$ & 4.56 \\
\hline Finding information & $\begin{array}{c}0 \\
(0)\end{array}$ & $\begin{array}{c}0 \\
(0)\end{array}$ & $\begin{array}{c}9 \\
(5)\end{array}$ & $\begin{array}{c}84 \\
(46.7)\end{array}$ & $\begin{array}{c}87 \\
(48.3)\end{array}$ & 4.43 \\
\hline Quizzes & $\begin{array}{c}0 \\
(0)\end{array}$ & $\begin{array}{c}0 \\
(0)\end{array}$ & $\begin{array}{c}15 \\
(8.3)\end{array}$ & $\begin{array}{c}80 \\
(44.4)\end{array}$ & $\begin{array}{c}85 \\
(47.2)\end{array}$ & 4.39 \\
\hline Giving feedbacks & $\begin{array}{c}0 \\
(0)\end{array}$ & $\begin{array}{c}0 \\
(0)\end{array}$ & $\begin{array}{c}18 \\
(10)\end{array}$ & $\begin{array}{c}96 \\
(53.3)\end{array}$ & $\begin{array}{c}66 \\
(36.7)\end{array}$ & 4.27 \\
\hline Downloading video & $\begin{array}{c}0 \\
(0)\end{array}$ & $\begin{array}{c}0 \\
(0)\end{array}$ & $\begin{array}{c}22 \\
(12.2)\end{array}$ & $\begin{array}{c}93 \\
(51.7)\end{array}$ & $\begin{array}{c}65 \\
(36.1)\end{array}$ & 4.24 \\
\hline Chat & $\begin{array}{c}0 \\
(0)\end{array}$ & $\begin{array}{c}15 \\
(8.3)\end{array}$ & $\begin{array}{c}37 \\
(20.6)\end{array}$ & $\begin{array}{c}85 \\
(47.2)\end{array}$ & $\begin{array}{c}43 \\
(23.9)\end{array}$ & 3.87 \\
\hline SMS & $\begin{array}{c}0 \\
(0)\end{array}$ & $\begin{array}{c}24 \\
(13.3)\end{array}$ & $\begin{array}{c}27 \\
(15)\end{array}$ & $\begin{array}{c}80 \\
(44.4)\end{array}$ & $\begin{array}{c}49 \\
(27.2)\end{array}$ & 3.86 \\
\hline MMS & $\begin{array}{c}6 \\
(3.3)\end{array}$ & $\begin{array}{c}29 \\
(16.1)\end{array}$ & $\begin{array}{c}44 \\
(24.4)\end{array}$ & $\begin{array}{c}73 \\
(40.6)\end{array}$ & $\begin{array}{c}28 \\
(15.6)\end{array}$ & 3.49 \\
\hline
\end{tabular}


This finding indicates that the situation preferences which attracts the attention of respondents whereby they are more likely into formal e-learning activity rather than informal activities.

\section{Conclusion}

This study has been able to produce the selection of mobile computing technology as the main equipment in the application of Arabic m-learning in the ITE. This prompted the selection of websites as a platform of operations and communication features that are more dominant in using this platform like email as compared to SMS and MMS. Similarly, the appropriate pat-tern of learning activities is included in the m-learning that focused on activities which parallel to the use of mobile com-puter technology.

\section{REFERENCES}

Abdul Aziz Mahayudin (2006). Konsep Kendiri Akademik dan Hubungannya dengan Penguasaan Bahasa Arab di Kalangan Pelajar PPISMP di Institut Perguruan Islam Selangor (IPIS). Jurnal Penyelidikan Pendidikan Institut Perguruan Islam Selangor.

Ahmad Sobri Shuib (2009). Reka Bentuk Kurikulum M-Pembelajaran Sekolah Menengah. Unpublished Philosophy Doctorate Thesis: Universiti of Malaya.

Asariah Mior Shaharuddin et.al (2009). The Next Generation of Teachers: Malaysian Perspective. $13^{\text {th }}$ UNESCO-APEID International Conference on Education and World Bank-Keris High Level Seminar on ICT in Education. Hangzhou China, 15-17 November 2009. Donwloaded on March 19th, 2011,from

http://ITEipoh.info/research/index

Goh Chin Shuang, Haslinda Md. Isa \& Poo Kuan Hoong (2009). Mobile learning application in foreign language learning : student survey feedback . e-Proceedings International Conference on E-Learning (2nd : 1-2 Dec 2009 : Shah Alam), editors: Posiah Mohd. Isa ...[et al.] (Shah Alam : University Publication Centre, Universiti Teknologi MARA, 2009).

Hayati Hashim, Koo Ah Choo \& Helena Song (2009). Exploring learner's perception of mobile learning. e-Proceedings International Conference on E-Learning (2nd: 1-2 Dec 2009 : Shah Alam), editors: Posiah Mohd. Isa ...[et al.] (Shah Alam : University Publication Centre, Universiti Teknologi MARA, 2009).

Mariam Mohamad \& John Woollard (2009) English language learning through mobile technology in Malaysian schools : an implementation strategy. e-Proceedings International Conference on E-Learning (2nd: 1-2 Dec 2009 : Shah Alam), editors: Posiah Mohd. Isa ...[et al.] (Shah Alam: University Publication Centre, Universiti Teknologi MARA, 2009).

Ministry of Education (2006). Education Development Master Plan 2006-2010. Kuala Lumpur : MOE

Nabeel Farouq Arif Al-Mushasha (2008). A model for mobile learning service quality in university environment. Philosophy Doctorate Thesis, Universiti Utara Malaysia.

Nimat Hafez Barazangi (2005). Arabic Self Learning : A Module of a Research-Based Compoterized Curriculum. Downloaded on March 18th, 2011, from

http://eself_learning_arabic.cornell.edu/publications/NHB_Al-Arabi yah_2005.pdf

Saedah Siraj dan Norlidah Alias (2005). Pembelajaran Mobile dalam kurikulum masa depan. Jurnal Pendidikan, Journal on Isues of Education, 27, 115-126.

Syed Ardi Bin Syed Yahya Kamal \& Zaidatun Tasir (2008). Pembelajaran Masa Depan - Mobile Learning (M-Learning) di Malaysia. Seminar Penyelidikan Pendidikan Pasca Ijazah 2008, 25-27 November 2008, Universiti Teknologi Malaysia.

Teacher Education Division (2010). Resolusi Seminar Pendidikan Islam dan Bahasa Arab Institut Pendidikan Guru. Putrajaya : KPM. 